\title{
Conflict Minerals From the Democratic Republic of the Congo- Gold Supply Chain
}

The U.S. Geological Survey (USGS) analyzes mineral and metal supply chains to identify and describe major components of material flows from ore extraction, through intermediate forms, to a final product. Supply chain analyses may be used to identify risks to the United States associated with the supply of critical and strategic minerals and metals and to provide greater supply chain transparency so that policymakers have the fact-based information needed to formulate public policy.

The USGS National Minerals Information Center (NMIC) has been asked by governmental and nongovernmental organizations to provide information about tantalum, tin, tungsten, and gold (collectively known as "3TG minerals") processing facilities worldwide in response to U.S. legislation aimed at identifying and removing the supply chain links associated with the trade of these metals and minerals among armed groups in the Democratic Republic of the Congo (DRC) and adjacent countries. Post-beneficiation processing plants (generally called smelters and refineries) for tantalum, tin, and tungsten (3T) mineral ores and concentrates were identified by company and industry association representatives as being the link in the $3 \mathrm{~T}$ mineral supply chain through which these minerals can be traced to their source of origin (mine). Tungsten processing plants were the subject of the first fact sheet in a series of USGS reports about 3TG minerals, which was published by the NMIC in August 2014 (Bermúdez-Lugo, 2014). Background information about historical conditions and the voluntary due diligence of multinational stakeholders for minerals from conflict-affected and high-risk areas is presented in the tungsten fact sheet. The current fact sheet, the fourth and last in the series about 3TG minerals, focuses on the gold supply chain.

Processing of the 3T mineral concentrates requires substantial infrastructure and capital and generally is done at relatively few specialized facilities that are not located at the mine site; primary and secondary processors typically are at separate locations. Gold, however, can easily be processed into semi-refined products at or near the mine site and has a high unit value in any form, which allows it to be readily exported through undocumented channels, making it more difficult to track to the mine or region of origin. To put this in perspective, 30 kilograms (66 pounds) of 83-percent-pure (20-carat) gold would form a cube measuring 12 centimeters per side (about the size of a small tissue box) and, at a price of $\$ 1,200$ per ounce, would be worth nearly $\$ 1$ million. By contrast, the equivalent value of tungsten concentrates would weigh about 45 metric tons (t) (100,000 pounds). Once conflict-sourced gold has been combined with gold from other mines and scrap at a refinery,

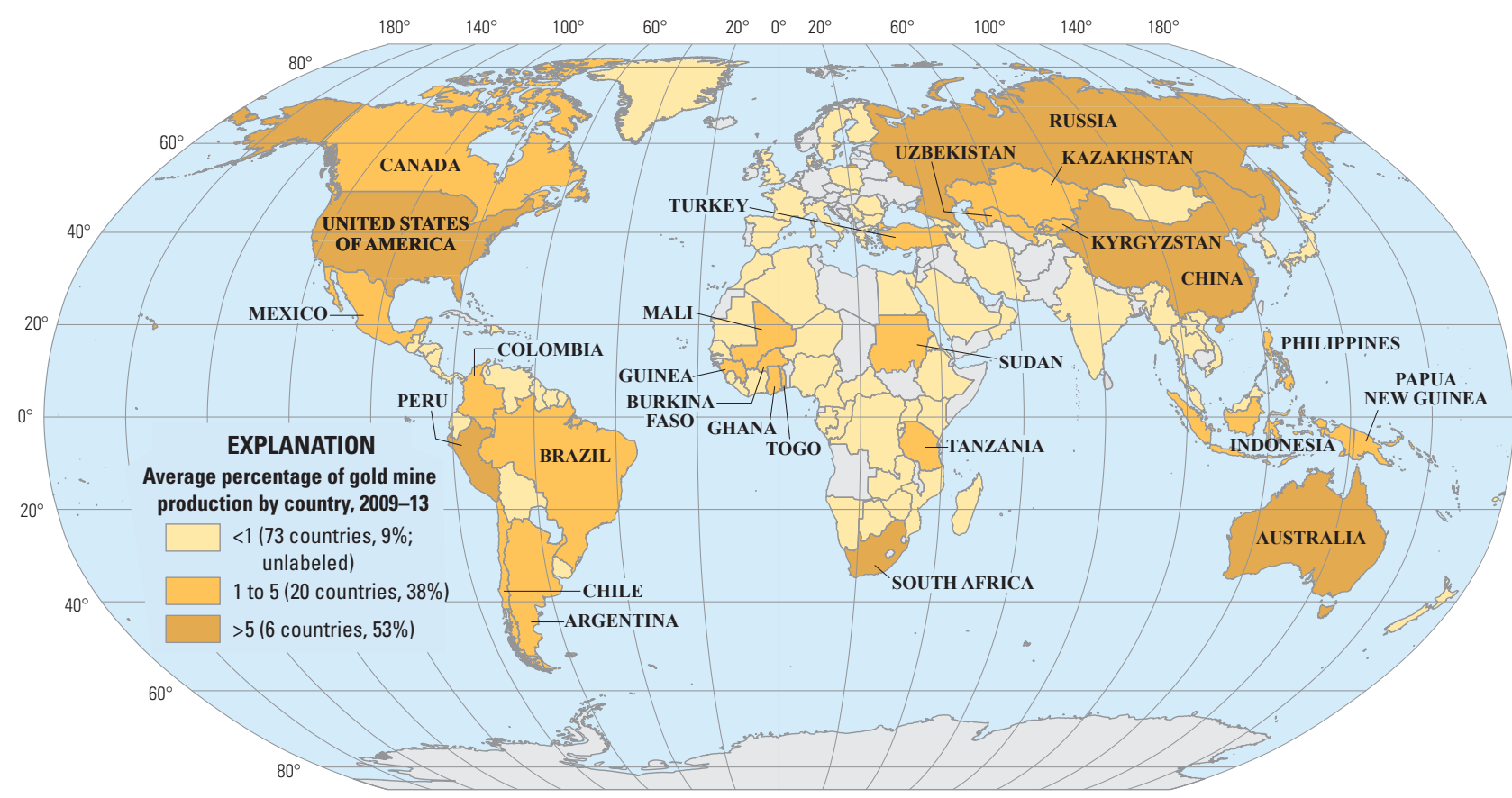

Average world gold mine production by country, 2009-13. 
there is no feasible way to distinguish the source of the gold. Thus, once the gold leaves the immediate area of production, it is nearly indistinguishable from gold products mined in other areas.

\section{Background}

Gold occurs naturally as native metal. It may be mined as a primary product from hard rock and alluvial placer deposits or recovered as a byproduct from copper, lead, platinum-group metals, silver, and zinc ores processing. Gold is chemically quite unreactive, although it will dissolve in aqua regia (a mix of nitric acid and hydrochloric acid). It is also malleable, ductile, and an excellent conductor of electricity and heat. Gold production was reported in almost 100 countries from 2009 to 2013; however, the six leading gold producers (in descending order of production) - China, Australia, Russia, the United States, South Africa, and Peru-accounted for 53 percent of global production. Gold has been treasured since ancient times for its beauty and permanence and remains the decorative metal par excellence. Gold is used as a store of value, because it does not degrade over time, can be easily recycled, and has a high intrinsic value. Throughout time, people have used gold as a form of wealth, whether it was in the form of bars, coins, jewelry, or artwork. About 7 percent of refined gold is used in nonmonetary applications such as electronic contacts, restorative dentistry, medical devices, and electromagnetic and infrared shielding, particularly in satellites.

\section{Global Gold Supply Chain}

Global gold supply, which begins at the mine, may involve large-scale industrial gold producers, byproduct gold recovery operations, placer mining operations, or artisanal and smallscale gold mines (ASGM). Small-scale mines may include semi-mechanized operations, while artisanal mines are dug by hand, using only rudimentary tools, such as shovels and sifters. Many ASGMs are in remote areas without adequate government oversight, further allowing for undocumented gold production and transport. The gold recovered is concentrated and at least partially processed at or near the mine. The larger scale mines typically produce doré bars that are mostly gold and silver. The ASGMs sell a concentrate (such as gold-bearing sand, gold flakes, gold nuggets, or gold amalgamate) to a local buyer. The local buyer collects the gold and then arranges to have the gold further processed.

Although large-scale refineries exist, numerous small refineries process doré bars, low-grade material, and scrap for use in jewelry fabrication or sale to other fabricators, thus bypassing bullion certification. Refineries may process gold from mines, old scrap, intermediate refineries, and other gold-bearing material to produce gold products (such as bullion, coin, foil, jewelry stock, powder, and wire). Unlike other metals, after the gold is recovered, it is considered as above-ground stockpile because it can easily be returned to the refineries to be recycled or transferred to other customers with little or no further processing. An estimated 7,500 to 8,000 metric tons (t) of gold

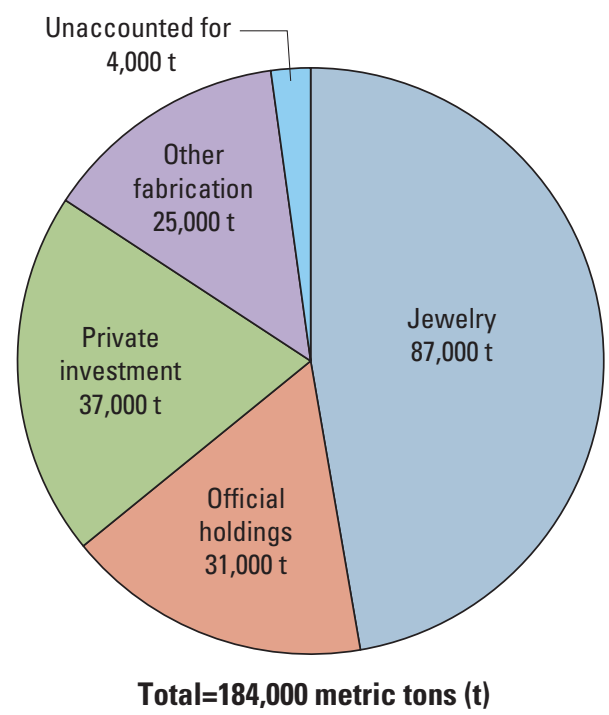

Estimated global above-ground stocks of gold as of yearend 2014. (Source: Thomson Reuters Ltd., 2015)

was refined in 2013, of which 2,800 t was from mine production, $1,600 \mathrm{t}$ was from old scrap, and the rest was from re-melting of semi-manufactured goods or bullion bars (London Bullion Market Association, 2015).

A major source of gold supply is the available aboveground stockpiles. Because gold is chemically unreactive and easily recycled, almost all the gold ever produced is still available for use. The estimated cumulative historical global gold mine production as of yearend 2014 was 184,000 t. At that time, about $31,000 \mathrm{t}$ was held by central banks as official stocks, about $37,000 \mathrm{t}$ was held privately as investments, about 87,000 t was held privately as jewelry, 25,000 $\mathrm{t}$ was in other fabricated products, and about 4,000 t was unaccounted for (pie chart, above) (Thomson Reuters Ltd., 2015, p. 52).

\section{Certified Gold Bullion}

To sell gold bullion, a refinery must be certified to produce certified pure gold. Table 1 lists the 10 gold bullion markets and the number of refineries certified to deliver gold bullion. Although the gold bullion markets listed contain only approximately 140 nonduplicate refiners of gold, the number of global refineries may exceed 500, and many of the refineries are listed on more than one bullion market. Most gold that is purchased by manufacturers and fabricators comes through one of these 10 markets; however, some manufacturers and fabricators purchase gold directly from refiners or purchase gold scrap for direct use. In 2013, the 72 refineries listed on the Good Delivery List, of the London Bullion Market Association (LBMA), the oldest and leading gold exchange, produced about 85 to 90 percent of globally refined gold (London Bullion 
Table 1. Gold bullion accreditors.

[NA, not available. Sources: Markets listed in the first column]

\begin{tabular}{|c|c|c|}
\hline Market & Country & $\begin{array}{l}\text { Number of } \\
\text { refineries }\end{array}$ \\
\hline BM\&Fbovespa $(\mathrm{BM} \& \mathrm{~F})^{2}$ & Brazil & 5 \\
\hline Shanghai Gold Exchange (SGE) ${ }^{2}$ & China & 30 \\
\hline The Chinese Gold \& Silver Exchange Society, Hong Kong (CGSE) ${ }^{2}$ & China & 12 \\
\hline Multi Commodity Exchange of India Ltd. $(\mathrm{MCX})^{2}$ & India & NA \\
\hline Indian Bullion Market Association (IBMA) & India & 8 \\
\hline Tokyo Commodity Exchange (TOCOM) & Japan & 44 \\
\hline Istanbul Gold Exchange $(\mathrm{IGE})^{2}$ & Turkey & 3 \\
\hline Dubai Multi Commodities Center (DMCC) & United Arab Emirates & 14 \\
\hline London Bullion Market Association (LBMA) & United Kingdom & 72 \\
\hline CME Group - Market Contract (COMEX) & United States & 27 \\
\hline
\end{tabular}

Market Association, 2015). Although these markets exist to certify that the gold bullion is pure gold, other organizations have initiated programs to certify that the source of the gold was not from a conflict region. Currently the LBMA, the Dubai Multi Commodities Center, and the World Gold Council have programs to document the source of the gold. More information can be found at the respective Web sites.

\section{DRC Gold Supply Chain}

The 2009-13 annual average gold production from the DRC and adjacent countries was about $87 \mathrm{t}$, which represents about 3 percent of the average global gold production during that period (table 2). The annual average worldwide gold mine production for 2009-13 was 2,650 t. Unlike the 3T minerals, the DRC has three large-scale industrial gold mines that produce gold for legal export: Kibali (Orientale Province), Namoya (Maniema Province), and Twangiza (South Kivu Province). These mines began production in 2012 or 2013 and produced $2 \mathrm{t}$ in 2012 and $5 \mathrm{t}$ in 2013. An estimated 11 to 14 metric tons per year were produced from ASGM operations in the eastern North Kivu and South Kivu Provinces and Ituri region (Yager, 2014). ASGM gold in the DRC and adjacent countries typically is recovered by panning or sluicing methods (gravity separation) that take advantage of the relatively high density of gold compared to other alluvial sediments. To further concentrate gold, ASGMs may use mercury in a process known as amalgamation. Following gravity separation, miners pour mercury into the gold-bearing sands and stir the mixture, often with their bare hands. The mercury and gold and (or) silver combine into a gray amalgam. The amalgam is then heated to boil off the mercury leaving behind very high concentrations of gold and (or) silver. A retort can be used to heat treat the amalgam so that the mercury can be captured and recycled. However, retorts are not used in most ASGM operations, and the mercury vapors can be released into the atmosphere with substantial human exposure and environmental health implications.

Table 2. Gold production from the Democratic Republic of the Congo (DRC) region, Africa, 2009-13.

[NA, not available. Source: George, 2015]

\begin{tabular}{|lc|}
\hline \multicolumn{1}{|c|}{ Country } & $\begin{array}{c}\text { 2009-13 average } \\
\text { (kilograms per year) }\end{array}$ \\
\hline Angola & NA \\
Burundi & $380^{\mathrm{e}}$ \\
Central African Republic & $56^{\mathrm{e}}$ \\
Congo (Brazzaville) & $140^{\mathrm{e}}$ \\
Congo (Kinshasa) (DRC) & $11,500^{\mathrm{e}}$ \\
Kenya & 2,450 \\
Rwanda & $8^{\mathrm{e}}$ \\
Sudan and South Sudan & $27,100^{\mathrm{e}}$ \\
Tanzania & 41,000 \\
Uganda & 260 \\
Zambia & $4,120^{\mathrm{e}}$ \\
\hline Total & 86,800 \\
\hline World total & $2,650,000$ \\
\hline 'Estimated. & \\
\hline
\end{tabular}


After the ASGM gold from the DRC and adjacent countries is recovered through gravity separation and amalgamation, it is sold to comptoirs (local gold buyers) who may further increase the purity before it is exported to a refinery. The gold collected by the comptoirs is generally more than 50 percent pure gold; the remainder is mostly silver. According to a United Nations report, about 98 percent of ASGM gold production in the DRC is exported illegally. One reported method of undocumented gold export is to transport the gold by boat across the Ruzizi River or Lake Tanganyika to Burundi, where it may be exported to a refinery (United Nations Security Council, 2015, p. 3). The same report surmised that approximately two-thirds of the gold illegally exported from the DRC passes through Uganda with smaller amounts shipped through Burundi and Tanzania.

After ASGM gold leaves the DRC region and arrives at a refinery, gold from other mines or scrap material may be blended, and the ability to identify gold sourced from a conflict region is almost impossible. Unlike the $3 \mathrm{~T}$ minerals, which are chemically heterogeneous, gold is often found in its elemental form and shows little or no chemical variation. Thus, it is unlikely that gold from a conflict region could be tagged as such through chemical analysis of the product.

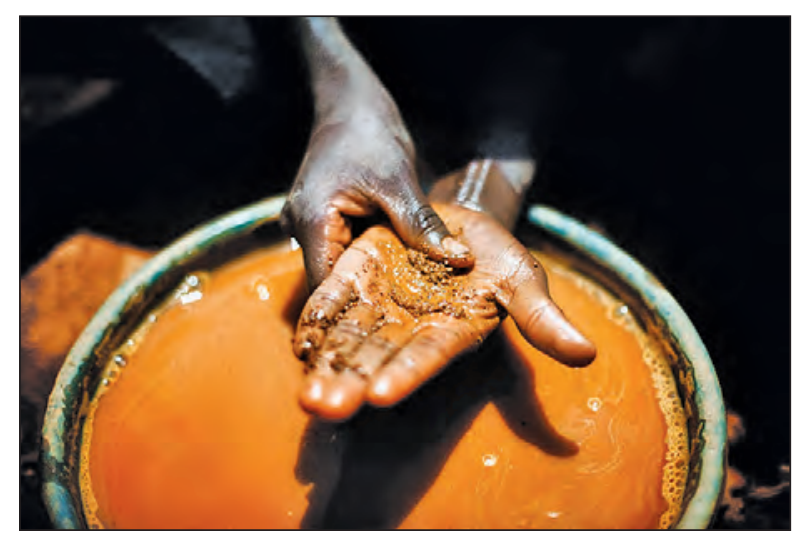

An artisanal miner pans for gold in the Democratic Republic of the Congo. (Photograph by Guillem Valle/Corbis)

\section{References Cited}

Bermúdez-Lugo, Omayra, 2014, Conflict minerals from the Democratic Republic of the Congo-Global tungsten processing plants, a critical part of the tungsten supply chain (ver. 1.1, August 2014): U.S. Geological Survey Fact Sheet 2014-3069, 4 p., accessed October 1, 2014, at http://dx.doi.org/10.3133/ fs20143069.

George, M.W., 2015, Gold [advance release], in Metals and minerals: U.S. Geological Survey Minerals Yearbook 2013, v. I, p. 31.1-31.18. (Also available at http://minerals.usgs.gov/ minerals/pubs/commodity/gold/myb1-2013-gold.pdf.)

London Bullion Market Association, 2015, A guide to the London Bullion Market Association: London, United Kingdom, London Bullion Market Association, 4 p., accessed June 12, 2015, at http://www.lbma.org.uk/assets/market/gdl/ LBMA Brochure Final 20150501.pdf.

Thomson Reuters Ltd., 2015, Gold survey 2014: London, United Kingdom, Thomson Reuters Ltd., April, 116 p.

United Nations Security Council, 2015, Final report of the group of experts on the Democratic Republic of the Congo: United Nations Security Council, S/2015/19, January 12, 2015, 277 p., accessed May 12, 2015, at http://www.securitycouncilreport.org/atf/cf/\%7B65BFCF9B6D27-4E9C-8CD3-CF6E4FF96FF9\%7D/s_2015_19.pdf.

Yager, T.R., 2014, The mineral industry of Congo (Kinshasa) [advance release], in Area reports-International-Africa and the Middle East: U.S. Geological Survey Minerals Yearbook 2012, v. III, p. 11.1-11.10. (Also available at http://minerals. usgs.gov/minerals/pubs/country/2012/myb3-2012-cg.pdf.)

By Micheal W. George, with contributions by Omayra Bermúdez-Lugo and Thomas R. Yager

\section{For more information, contact}

Director, National Minerals Information Center

U.S. Geological Survey

12201 Sunrise Valley Drive

988 National Center

Reston, VA 20192

Email: nmicrecordsmgt@usgs.gov

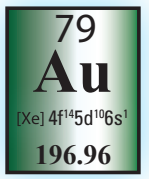

Or visit the USGS Minerals Information Web site at http://minerals.usgs.gov/minerals/ 